\title{
Walrus Ivory and a History of Trade: Greenland Trade Networks in the North Atlantic
}

\author{
By Courtney Svab
}

Norse settlement in Greenland represents the far westward reach of Norse influence. Despite being a considerable distance from other settlements, the Greenland colony was not nearly as isolated as it appeared. The Greenland Norse were involved in extensive trade networks which linked the North Atlantic Norse world. These networks allowed for the exchange of communication and commodities for hundreds of years, creating a system that was imperative to the success of the Greenland settlements. The trade routes connecting Greenland to the rest of the North Atlantic provide an interconnected understanding of the relations between Norse settlements in the North Atlantic. Understanding the economic connections of the North Atlantic presents a new way to interpret the political organization of Norse society and the motivations that pushed its expansion to the west. This understanding allows for the interactions between Greenland and the rest of the North Atlantic to be examined for their significance and the economic benefits that supported the Greenland settlement. The paper will first examine how trade in Scandinavia prior to expansion to Greenland developed. This includes focusing on the commodities being traded, the key areas of trade, and the development of social trade norms. By examining the existence of trade, motivations for the settlement of Greenland can then be reevaluated through the opportunity for economic expansion. Next, the goods available from Greenland and Norway will be examined to evaluate the value of trade across the North Atlantic. This involves examining not only the commodities available, focusing primarily on walrus, but also examining the vessels of trade that fueled the North Atlantic trade network. Finally, in order to evaluate the practical applications of the trade network, a case study will be examined. The case study that will be highlighted will be of the Lewis Chessmen. Key sources to determine early Norse economic interests include the Voyage of Ohthere, as well as archaeological evidence of trade such as walrus tusks and the Lewis Chessmen.

Trade existed as a way to connect Scandinavia and Europe for hundreds of years before Vikings settled Greenland. Prior to the settlements, the development of trade began with the exchange of tribute collected by the Norse from the Sami in northern Norway. This interaction is first recounted in the Voyage of Ohthere, where a traveller by the name of Ohthere describes his voyages in the north to the Anglo-Saxon King Alfred in the late ninth-century. Ohthere is a 
traveller from Hålogaland, which was the furthest north any Northmen, or Norwegians, lived. ${ }^{1}$ Ohthere's account serves as a survey of the land of northern Norway and the possible commodities available there. In his voyage, Ohthere makes note of the importance of the wild animals, such as walrus and reindeer, as commodity. ${ }^{2}$ Following the identification of commodities to be found in the North, Ohthere draws the connection between the importance of taxation and tribute extracted from the Sami as the primary source of wealth for the Norwegians through discussing the origins of his wealth. He tells King Alfred that he does not possess a great number of cattle or sheep and therefore supplements his wealth through interaction with the Sami. The tax collected by the Norse was dependant on social rank and consisted mostly of wild animals' products such as animal skins, bird feathers, whale bones, or rope made from whale or seal hide. ${ }^{3}$ Ohthere then finishes his account with a description of the sailing trip from the north of Norway to the trading town of Hedeby in Denmark. This exchange of tribute through tax is significant in understanding the development of trade in Scandinavia due to it representing the beginning of the movement of goods from one culture to another. These were goods the Norwegians required and were able to extract from the Sami. The evidence of the important sailing routes to Hedeby as outlined by Ohthere provided further evidence of the relevance of trade for the Norwegians and the importance of animal goods. By recounting the voyage to Hedeby, Ohthere is showing the role the trading centre played in early medieval life as it is a voyage he had undergone numerous times in order to describe the sailing directions to King Alfred. The importance of the connections with the Sami and the trading centre of Hedeby is shown through the way that he chooses these particular voyages to tell King Alfred about as well as why they were recorded at the court of the King.

The political organization of early Scandinavia that allowed for the tribute given to the Norwegians serves to provide further understanding of Ohthere's voyages and the society that developed. The Voyage of Ohthere provides a way for historians to analyze the early political organization of Scandinavia through the way that Ohthere encounters the different lands to which he travelled. Stefan Brink suggests that the way Ohthere describes the land of the Northmen suggests that though they were not organized into one set kingdom, Ohthere presents a sense of unity among the different regions of Norway. ${ }^{4}$ This interpretation of the political structure of early Norway can be used to explain why it was the Sami that were required to pay tribute rather than the other regions of Norway despite the absence of a king. By presenting a sort of unity among regions, the social structure of the early Scandinavians left the Sami as the 
outsiders from whom they could collect tribute. The lands discussed through Ohthere's voyages also shed light on the wider political situation of early Scandinavia. The Danish are presented as a key empire with whom it was important to be allied in order to gain access to the trading centres. ${ }^{5}$ By being a united force, Denmark is able to monopolize the key trading areas and the Norse interactions with Denmark reveal the politics of neighbouring lands. Through this, Denmark is able to possess economic, political, and cultural power over the area in the ninthcentury. ${ }^{6}$ For example, there is a lord at Hedeby, but there is not one mentioned at Skiringssalr. Brink takes this as a sign that the lord at Skiringssalr was possibly not under Danish control, and therefore Ohthere does not mention him. ${ }^{7}$ This points to the Danish as being the important players in early Scandinavian trade.

The early trade as recorded by Ohthere was not just an exchange between a couple settlements; it was a vast network connecting Northern Europe. This vast trade network was conducted by a series of professional traders who were independent from any one place of trade. ${ }^{8}$ These traders had the ability to travel across Europe with their goods to interact with numerous cultures. The traders are mentioned in a number of sources, primarily annals such as the Annales regni Francorum and are commonly referred to in relation to the actions of the rulers. ${ }^{9}$ One example of this is the Danish King Sigfred who attempted to achieve a special peace with the Saxons in 873 that would allow for the safety of tradesmen pursuing business. ${ }^{10}$ Accounts such as that of King Sigfred demonstrate that the evidence of thriving trade as early as the ninthcentury is found through primarily legal documents. The fact that in all the accounts, such as the annals or Ohthere's voyages, trade is such an important focus confirms that trade routes between regions had an important societal role and was already well developed prior to the recording of these sources in order to have such a prominent place in the sources. Trade served to connect nations, and the rulers of different kingdoms kept the wellbeing of trade in mind through various policies. The trade networks benefited not only the merchants, but also the rulers through the revenue they collected. From the outset of this trade, the rulers were interested in the traders and sought to strengthen their own positions through the exchange of valuable goods. This created a relationship wherein the traders sought the protection and favour of the king, and the ruler found it useful to keep the merchants close to them in order to collect taxes from the trades. ${ }^{11}$ The tradition of trade portrays the Scandinavians as traders despite their later reputation as sea-faring raiders. It is interesting to note that the Vikings may have known where to raid due to their knowledge of trading ports, however, trade across Northern Europe was not disrupted due to the 
raiding activities of the Vikings. ${ }^{12}$ This could have indeed led to the expansion of trade networks as new lands were conquered. The evidence of this early trade supports the formation of a Scandinavia that valued the long-standing tradition of trade, laying the ground work for a North Atlantic trade network.

The Scandinavian trade network, though spread across Northern Europe, was strongest in the North Sea area. This involved trade with Frisia, which linked the North Sea with the Kingdom of the Franks and is best traced through the development of coinage. Frisia, located in the modern Netherlands, was settled primarily near the coast, connecting it directly with Scandinavia. ${ }^{13}$ Trade between the two cultures formed out of necessity. The Frisians faced poor agricultural prospects, causing a dependence on trade that arose in the seventh-century. ${ }^{14}$ The reliance of the Frisians on trade sparked the movement of people and goods across the North Sea in the seventh-century. In the eighth-century the Frisians were well established as the crossroads between the Franks and the Scandinavians. ${ }^{15}$ Primarily traded were the required goods from Scandinavia with goods from the Rhine area of Northern Europe. The goods traded through the North Sea network included raw materials such as salt, honey, beeswax, furs and leathers, whale bone, and walrus tusks from the Scandinavians in exchange for luxury goods from the Rhine, such as ceramics and glassware, as well as slaves. ${ }^{16}$

The increase in trade in the North Sea area led to the development of blank silver coins called sceattas that were not issued by a particular ruler, but were used to facilitate trade. ${ }^{17}$ These coins allow for trade to be traced throughout the North Sea area by tracking the movements of traders through the types of coins that are found at trading sites and in hoards. With the rise of the Carolingian empire in the late eighth-century, the nature of trade changed once again. The Carolingians introduced a new silver coin called the denarius in order to bring the minting of currency under central control as well as to provide a currency that would aid in facilitating longdistance trade. ${ }^{18}$ This represents the growing interest in trade and economics by the rulers involved in this North Sea trade route. Further, the coins developed by Charlemagne rose in popularity following the succession of Louis the Pious. The Frisian trading town of Dorestad minted the coins, solidifying it as a key centre of commerce in Northern Europe. The presence of coins in Scandinavia, as well as Europe support the theory of ongoing active trade that connected Europe. ${ }^{19}$ It is important to understand these connections with Northern Europe in order to track the development of trade across a North Atlantic network. 
Coins present a way to track Scandinavian trade and the way it developed across Europe. Prior to trade, the Viking society of the eighth-century that formed at the outbreak of raiding had little experience with coins. ${ }^{20}$ Indeed at the start of the period of raiding, Charlemagne had not yet centralized the production of the denarius. By the early eleventh-century, Scandinavian rulers across the Viking world had adopted the use of coins into their economies. ${ }^{21}$ The change from weighed amounts of silver, which had been used to facilitate trade, to coins can be traced archaeologically through the evidence found in hoards. By the second half of the tenth-century, coins became more predominant in Viking hoards and by the early eleventh century, the number of coins found in archaeological sites had overcome the amount of silver artifacts found. ${ }^{22}$ This shows the growing involvement of the Scandinavians in fostering trade with other cultures despite the ongoing presence of Viking raiding. Particularly influential in the development of Viking coins was the Anglo-Saxon model. Vikings in England began making their own coins by $890 \mathrm{CE}$, influenced by the proximity to an abundance of German coins. ${ }^{23}$ The influence of the growth in the use of coinage elsewhere allowed for the Scandinavian trade networks to expand and adopt the use of coinage.

The trade networks that emerged included local and long-distance trade. It is crucial to understand how this trade was facilitated in order to determine the prerequisite that existed for trade across the North Atlantic. The shift in the ninth-century towards the development of trading centres, such as Hedeby, and the widespread distribution of coins across Northern Europe led to the formation of the economic centers of early Scandinavia. The trade connections that fostered the building of these vast networks in the eighth and ninth centuries gave way to fortified trading centres, the increased popularity of coins, and innovations in ship technology in the tenthcentury. ${ }^{24}$ This led to an evolution in trade and exchange networks that allowed for the growth and development of commerce in the Viking world. These changes were important in the development of long-distance trade networks used by the Norse in later periods. The earlier manifestations of trade networks are important to study as part of a developing process of trade that spread across the Scandinavian world.

Meanwhile, long-distance trade occurred through a series of specific locations where large bulks of materials were loaded or unloaded from the ships. ${ }^{25}$ The sites that facilitated longdistance trade varied from those that were purely for local trade. The archaeological record shows that the sites that facilitated long-distance trade frequently have large deposits of raw material, such as bronze casting. ${ }^{26}$ The same few sites would have served as primarily long- 
distance trading centres as they presented popular and reputable places for merchants to congregate. $^{27}$ This presents trade as a way to foster relations between different cultures as they were trading in the same few locations across Europe and Scandinavia. With the introduction of the North Atlantic trade routes, the networks connecting Europe with the rest of the Norse world expanded.

The Norse society that formed these vast networks of trade developed a trading network dependent on mutual trust to ensure its efficiency. This was due to the inability of the early Vikings to read or write, meaning that the laws of trade were not codified in a documentary source. This meant that they relied on a series of social conducts and trust to carry out trade. ${ }^{28}$ This type of trading put specific emphasis on the weight of a man's word and his honour. The value of a man's word and honour was connected to his credibility and social worth. ${ }^{29}$ The word of a Scandinavian man was what gave him his credibility as a trader and allowed for him to participate in the exchange of material and culture. The importance of honour in the Norse society is seen through their language and the sheer number of times that the early word for honour virðing appears in documentary sources. ${ }^{30}$ This word appears numerous times in sources, pointing to its relevance in society. Through the development of a social culture dependent on mutual trust, a unique type of trade was built in the Norse world that affected the way trade was conducted.

In order to understand the significance of the trade routes that stretched across the North Atlantic, connecting Norway and Greenland, the motivations for the settlement of Greenland need to be evaluated. Recently, Christian Keller proposed that the settlement of Greenland was motivated primarily due to the economic opportunity for trade. Keller proposes that, having only been settled in the $870 \mathrm{~s}$, there was no way that Iceland was overpopulated by $1000 \mathrm{CE}$. $^{31}$ This means that the traditional view of motivation based purely on settlement of Greenland is not supported. Keller breaks apart the theory of settlement for land that has dominated the way the settlement of Greenland is interpreted by further pointing out the futility of relying on pastoral living in the arctic. ${ }^{32}$ Instead, Keller looks at the commodities available in Greenland coupled with the existing networks of trade that dominated the Norse world as more viable motivations for settlement. The economic motivations for settlement in Greenland present a new interpretation of the nature of the settlement as well as the Norse purpose for westward expansion. Unlike Iceland, Greenland was home to a plethora of exportable goods. ${ }^{33}$ The particular goods that inspired trade were primarily walrus ivory, furs, and fish. These were 
considered luxury goods on the European market. The Norse expansion into Greenland is reminiscent of the Norse expansion into the Sami territory as seen through the Voyage of Ohthere. ${ }^{34}$ The goods collected through the trade with the Sami are reminiscent of the goods that were exported from Greenland. This shows that the Norse were aware of the luxury goods available and sought additional resources in order to continue to facilitate trade with the rest of Europe. While looking at economic motivations for settlement in Greenland, Keller also proposes economic reasons for the abandonment of the Greenland settlement. His theory is that the outbreak of the Black Plague in Europe coupled with the end of the Medieval Warm Period and the resulting dangerous seas saw the fall of the North Atlantic trade routes. ${ }^{35}$ The Plague and the change in weather served as factors leading to the end of trade via Greenland, leading to the loss of an economic system and the subsequent abandonment of the Greenland settlement. This theory supports the economic motivations of the settlement while also addressing economics as the main purpose of the colony due to its abandonment following the cessation of economic use.

The documentary sources dealing with Norse expansion into the North Atlantic are primarily Icelandic saga texts. However, sagas have come under scrutiny by historians due to the composition of sagas dating to the twelfth and thirteenth centuries while the events described took place hundreds of years earlier. Settlers in Iceland followed an oral tradition in passing along stories despite that the use of literacy arrived in Iceland along with conversion to Christianity. ${ }^{36}$ The saga concerning the settlement of Greenland is the Greenlanders' Saga. Coupled with archaeology, there is ample evidence of the settlement patterns of those who went to Greenland with Eirik the Red. Settlement in Greenland relied on the adoption of the Scandinavian pastoral farm method, wherein the amount of land signified wealth and animals were grazed on an in-field/out-field method. ${ }^{37}$ The earliest evidence is found at what is thought to be the site of Eirik's farm, Brattahlíð, which contained an early church built by his wife Thjodhild. ${ }^{38}$ The artifacts found here, along with the skeletons buried at the early church, place earliest settlement from the end of the tenth-century and spanning into the early eleventh. ${ }^{39}$ This evidence is not the only way that the conditions for the Norse settlers are determined. Studies of cores drilled from the Greenland icecap provide further information about the conditions that dictated the Greenland settlement. The ice cores revealed that the temperature began to rise in the $860 \mathrm{~s}$, leading to the favourable phenomenon referred to as the Medieval Warm Period. ${ }^{40}$ The end of the Medieval Warm period is also represented in the ice cores and the weather can be seen 
decreasing by the middle of the thirteenth-century. ${ }^{41}$ These sources allow historians to understand the factors that affected the settlers in Greenland and their daily lives.

The key export from Greenland was walrus ivory. Walrus ivory was used to create intricately carved figures, while the rest of the walrus could be used for fashioning strong rope used on ships. ${ }^{42}$ The walrus ivory especially was featured in the luxury goods trade on the European market. Prior to the discovery of Iceland, and later Greenland, walrus ivory was an important commodity that could only be obtained from Northern Norway and the Sami. ${ }^{43}$ This familiarity with walrus ivory shows that the Norse were accustomed to working with and aware of the use of walrus ivory, supporting Keller's theory that the Norse settled Greenland for economic reasons. In order to hunt for walrus, the Norse often ventured to Northern hunting grounds referred to as Norðseta. This hunting ground is in the northern Disko Bay area of Greenland and was often accessed by the Norse during the summer months. ${ }^{44}$ The northern location of the Norðseta places it in the same northern environment as the earlier exploitation of the Sami. This further supports the theory that the settlement of Greenland was economically motivated as the walrus hunts would have taken place over the summer months when agriculture is at its height as the hunt took away from other priorities, such as farming, that would have taken precedence had the settlement been primarily land-based. ${ }^{45}$ This leads to the theory that the Greenland settlement worked together as a community to not only ensure the agriculture was taken care of, but also to butcher the walrus. The nature of the walrus trade itself also points to a cooperative network wherein the trade of walrus tusks was highly organized and the ivory would have passed through numerous hands before arriving at its final destination. ${ }^{46}$ This is supported from the find of walrus bones in numerous farms in both the East and West Settlements of Greenland. ${ }^{47}$ This is supported by the existence of small settlements in Greenland and the evidence of scheduling conflicts that arose during peak times of the year such as the summer.

Walrus ivory was popular in Europe, resulting in an economic trade between Norway and Greenland. It was especially popular after the mid-ninth-century when elephant ivory became more difficult to obtain. ${ }^{48}$ Prior to the mid-ninth-century, elephant ivory had been more popular than walrus ivory due to the size of the elephant tusks versus that of the walrus. Walrus ivory had been used before the loss of access to elephant ivory, however not to the same extent or popularity. ${ }^{49}$ It was common to bring the whole skull of the walrus back to the settlement after hunting in order to properly remove the tusks so as not to damage the ivory. The extraction of the walrus ivory was completed by skilled hunters in order to avoid any damage. After killing the 
walrus, the frontal bones were discarded in order to maximize the space in the boats for the journey back to the settlements. ${ }^{50}$ The remains would then be stored to ensure a slight decay. This process would take place over the winter so that the tusks were ready to be traded the following summer. ${ }^{51}$ Evidence of skull fragments in Greenland settlement sites supports the theory that the tusks were removed from the skulls while at the farms in order to ensure that the tusks were ready for the market and were of a high quality. ${ }^{52}$ In contrast, some walrus skulls have been found in Europe as well, suggesting that occasionally the skull and tusks would be used for exotic display. ${ }^{53}$ These would have been gifts for important chieftains or leaders as a way to show off these figures to show off their wealth. However, the settlement was dependent on the demand for walrus ivory. Elephant tusks once again became more readily available and therefore more popular in the thirteenth-century. ${ }^{54}$ There was also a period around $1400 \mathrm{CE}$ where all types of ivory fell out of fashion. ${ }^{55}$ This directly relates to the fall of the Greenland settlement due to the economic reliance of the colony on the trade network. With walrus ivory no longer in demand on the European market, there was a lack of demand for the main export from Greenland. Greenland was also very dependent on goods imported from Europe, and without this trade to further the economic exchange the settlement faced more difficulties. Combining this with the end of the Medieval Warm Period and the plague that swept across Europe, and Greenland was suddenly an undesirable location.

The Greenland settlement represents the trade model of supply and demand in both imports and exports. Greenland, though not self-sufficient, was able to provide some basic materials to allow for survival. This included large herds of cattle and sheep, the availability of walrus, the growth of some grain, homespun cloth, and the manufacture of items from local soapstone. ${ }^{56}$ These items ensured the day-to-day survival of the settlement. In addition to the primary export of walrus ivory, another important export were Greenland falcons, which were rare outside of Greenland and became a luxury export to the European market. ${ }^{57}$ The colony was reliant on the importation of goods, primarily timber and iron ${ }^{58}$ Trade with Scandinavia was primarily across the North Atlantic, skipping from Greenland to Iceland to Norway. This was a way to connect the North Atlantic world through the economics of trade. Norwegian merchants would sail to Greenland one summer, then sail back to Norway the next. ${ }^{59}$ This allowed for the familiarization of merchants and settlers, and fostered the growth in relations between Norse settlements. Trade not only allowed for the exchange of goods, but also the exchange of culture. When the merchant ships would land at the settlements, there was often a gathering to examine 
the goods as well as to exchange news. ${ }^{60}$ This shows that though the settlement was dependent on trade for survival, the existence of this North Atlantic network was critical for maintaining an interconnected Norse empire.

In order to foster this North Atlantic connection, there was a critical change made in the type of boat used to transport goods across the sea. The late tenth century provides a number of finds that show an increased specialization of ship type, reflective of the growing centralization of power and the rise of commercial trading. ${ }^{61}$ The long ship that was a key feature of the Viking raids began to give way to a sturdier cargo ship. The ship evolved into a model that could be manned by a smaller crew, had a large holding capacity and was propelled primarily by sail. ${ }^{62}$ This change in ship type is significant in facilitating the change from raiders to traders and marks the change in society. The earliest ship found of this new cargo type is the Klåstad ship. It was built near the end of the tenth century and sunk near the trading center of Kaupang. ${ }^{63}$ Further evolutions in ship design, such as the Norwegian built Skuldelev I, allowed for the improvement in long-distance sea going vessels. The Skuldelev I had a capacity of 24 tons and could be manned by a crew of five to seven. ${ }^{64}$ This allowed for the increase of cargo required for long distance trade while reforming the standard Viking ship from a vessel of terror to a vessel of trade. It is likely that the evolution in ships came about earlier than the archaeological record shows. The change in ship type is significant for the North Atlantic trade route through the new vessels' ability to transport greater numbers of people and animals across the vast distances of the sea. The specialization of ship type is also representative of the change in social structure. It represents the growing stratification of society resulting in the rise of commercial enterprise. ${ }^{65}$ The political organization required for this stratification reveals that by the tenth-century, power in the Viking world was centralized and trade had become an important factor in reinforcing this system.

An important case study for the exchange network between Greenland and the rest of the North Atlantic is the case of the Lewis Chessmen. The Lewis Chessmen represent the trade networks that connected the North Atlantic because the chessmen are carved from walrus ivory from Greenland but were found on the Isle of Lewis in the Hebrides of Scotland. The Lewis Chessmen may have originally been coloured over top of the ivory, which would have increased their economic value. ${ }^{66}$ The surface of the Chessmen can be analyzed to reveal physical information about the Chessmen. In her analysis of the facial features of the Chessmen, Caroline Wilkinson grouped the figurines into groups of five distinct features. She concluded that these 
groupings point to the work of at least five workmen carving the Chessmen in the same workshop. ${ }^{67}$ This is evidence of the increased development of an exchange network that involved the labour of not only hunters and traders responsible for the movement of the walrus itself, but that the society supported specialized artisans who could carve the raw material of walrus ivory into finished goods. It is agreed upon that the Chessmen were likely carved in Norway at one of the trading centers. ${ }^{68}$ By further analyzing the surface, the materials used for the Chessmen can be examined. While most of the Chessmen are made using walrus ivory, five of the Chessmen were made using whale teeth. ${ }^{69}$ This is significant in understanding the process of trade and walrus hunting and the way the Chessmen were carved through the prominence of walrus ivory from Greenland as a material over the use of whale teeth. The tool marks on the Chessmen also show the practices of the medieval workmen. In addition to carving marks, several of the pieces had multiple small horizontal lines along the sides, signifying they may have been held in clamps during the carving process. ${ }^{70}$ This expands the knowledge of the practices of the medieval workmen and the processes of the artistic work carried out as a part of this exchange network.

The Lewis Chessmen also present an interesting look at how the North Atlantic was connected through various North Atlantic kingdoms. The Kingdom of the Isles and Man included the Isle of Man and the islands off the west coast of Scotland. The Kingdom was of Scandinavian origin and developed into a maritime kingdom based in the Irish Sea. ${ }^{71}$ This included the Isle of Lewis where the Chessmen were found. This begs the question of to what extent were the Manx kings involved in the Lewis Chessmen. The presence of many high ranking officials based in the Outer Hebrides at the turn of the twelfth and thirteenth centuries extends the possibility that perhaps one of the Manx rulers was in possession of the chess pieces. ${ }^{72}$ Regardless of who owned the chess pieces, the pieces are representative of a stratified society that developed vast trade networks. The possessor of the Chessmen was likely a wealthy leader who would have participated in this trade in order to possess luxury goods that would reflect his or her level in society. The Lewis Chessmen are representative of the North Atlantic trade and the ways that different settlements were able to maintain contact and exchange throughout the tenth to thirteenth centuries. The Lewis Chessmen were made of primarily walrus ivory from Greenland, and the manufacturing marks left behind by the skilled craftsmen indicate different levels of exchange from raw materials to a finished product to be traded for other goods or gifted to a wealthy ruler, demonstrating the different stages of trade that took place across the North Atlantic. The markings on the Chessmen and the way they were carved place them in 
Norway before they ultimately ended up in Scotland, emphasizing the movement of goods. ${ }^{73}$ The process through which the Lewis Chessmen came to the Isle of Lewis is an example of the processes that linked the North Atlantic, forming a type of Norse Empire.

The North Atlantic trade routes are significant in the development of an interconnected understanding of Norse settlement and activities in the North Atlantic. Greenland was not an isolated settlement that struggled with arctic conditions during its lifetime. Greenland instead represents the culmination of a widespread economic society with enough of a centralized political organization to present an intricate trade network that spanned thousands of kilometers. In order to understand the development of the North Atlantic the development of trade in Scandinavia must be traced. The development of trade norms revealed the established trade networks and the focus on the goods provided by walrus such as hides or ivory. This shows that there was a development of trade networks and a shift in society to an economic focus that shaped future expansion towards the west. Recent scholarship has proposed that the establishment of a trading society in Scandinavia motivated the settlement of Greenland with primarily economic concerns. This indicates a change in the nature of the settlement in Greenland and the way that the process of settlement and travel to North America should be studied. The economic purposes of the Greenland settlement focused on the exportation of walrus ivory to the European luxury market. This trade motivated the development of a network connecting Greenland with the rest of the Norse world. The case of the Lewis Chessmen provides a way to examine the movements of trade goods across the North Atlantic. Made with walrus ivory in Greenland, they were likely carved in Norway before moving to the Isle of Lewis in the Hebrides. This provides an example of the highly-organized system of trade that required the cooperation and interaction of many groups spanning across the North Atlantic. The settlement of Greenland and the North Atlantic trade routes are significant in understanding how these different elements of trade, survival, and commerce connect the North Atlantic.

\section{NOTES}

\footnotetext{
${ }^{1}$ Janet Bately, “Text and Translation," in Ohthere's Voyages: a late $9^{\text {th }}$ century account of voyages along the coasts of Norway and Denmark and its cultural context, eds. Janet Bately and Anton Englert (Roskilde: Viking Ship Museum, 2007), 47.

2 Ibid., 45-46.

${ }^{3}$ Ibid., 46.
} 


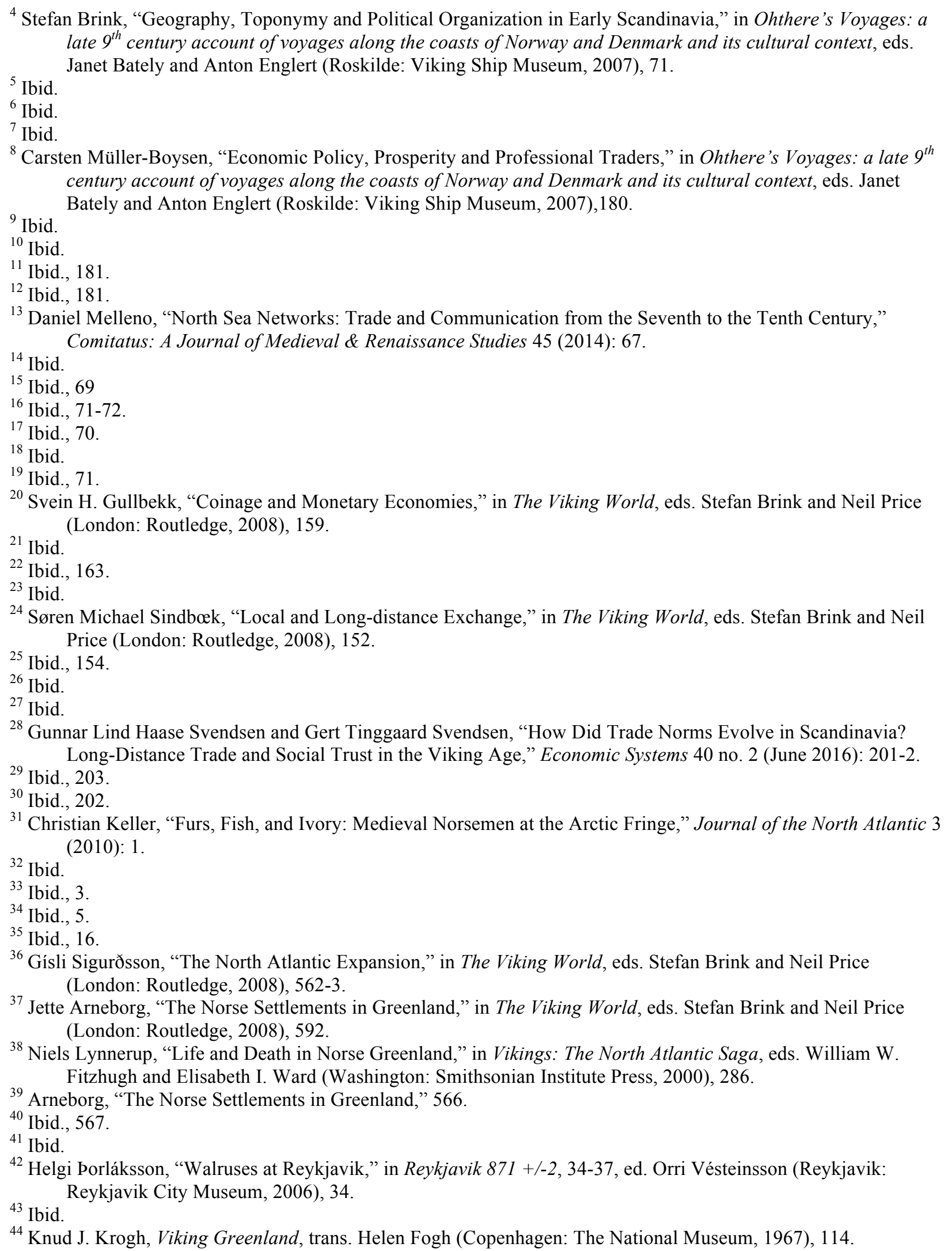


${ }^{45}$ Karin M., Frei Ashley N. Coutu, Konrad Smiarowski, Ramona Harrison, Christian K. Madsen, Jette Arneborg, Gardar Guethmundsson, Soren M. Sindbaek, James Woollett, Steven Hartman, Megan Hicks, and Thomas H. McGovern, "Was it for Walrus? Viking Age Settlement and Medieval Walrus Ivory Trade in Iceland and Greenland," World Archaeology 47 no. 3 (September 2015): 446.

${ }^{46}$ Else Roesdahl, "Walrus Ivory - Demand, Supply, Workshops, and Greenland," in Viking and Norse in the North Atlantic: Select Papers from the Proceedings of the Fourteenth Viking Congress, Tórshavn, 19-30 July 2001, eds. Andras Mortensen and Símun V. Arge (Tórshavn: Annales Societatis Scientiarum Færoensis Supplementum XLIV, 2005), 187.

${ }^{47}$ Frei, et al., "Was it for Walrus?" 446.

${ }^{48}$ Roesdahl, "Demand, Supply, Workshops, and Greenland," 184.

${ }^{49}$ Ibid.

${ }^{50}$ Elizabeth Pierce, "Walrus Hunting and the Ivory Trade in the North Atlantic," in The Lewis Chessmen: New Perspectives, eds. David H. Caldwell and Mark A. Hall (Edinburgh: National Museums Scotland, 2014), 170.

${ }^{51}$ Ibid.

${ }^{52}$ Roesdahl, "Demand, supply, workshops, and Greenland,"187.

${ }^{53}$ Ibid.

${ }^{54}$ Ibid., 184.

${ }^{55}$ Ibid.

${ }^{56}$ G.J. Marcus, "The Greenland Trade-Route," in The Economic History Review 7 no. 1 (1954): 71.

${ }^{57}$ Kirsten A. Seaver, The Last Vikings: The Epic Story of the Great Norse Voyages (London: Palgrave Macmillan, 2010), 102

${ }_{58}^{58}$ Arneborrg, 304. (North Atlantic Saga)

${ }^{59}$ Marcus, "The Greenland Trade-Route," 72.

${ }^{60}$ Ibid.

${ }^{61}$ Jan Bill, "Viking Ships and the Sea," in The Viking World, eds. Stefan Brink and Neil Price (London: Routledge, 2008), 174.

${ }^{62}$ Ibid., 176.

${ }^{63}$ Ibid.

${ }^{64}$ Ibid.

${ }^{65}$ Ibid.

${ }^{66} \mathrm{Jim}$ Tate, Ina Reiche, and Flavia Pinzari, "The Lewis-Chessmen: What Can Examination of the Surfaces Tell Us?" in The Lewis Chessmen: New Perspectives, eds. David H. Caldwell and Mark A. Hall (Edinburgh: National Museums Scotland, 2014), 11.

${ }^{67}$ Caroline Wilkinson, "The Facial Analysis of the Lewis Chess Pieces," in The Lewis Chessmen: New Perspectives, eds. David H. Caldwell and Mark A. Hall (Edinburgh: National Museums Scotland, 2014), 8.

${ }^{68}$ R. Andrew McDonald, "The Manx Sea Kings, the Isle of Lewis and the Gaming Pieces: Is There a Manx Context for the Lewis Chessmen?" in The Lewis Chessmen: New Perspectives, ed. David H. Caldwell and Mark A. Hall (Edinburgh: National Museums Scotland, 2014), 96.

${ }^{69}$ Tate, Reiche and Pinzari, "What Can Examination of the Surfaces Tell Us?" 13.

${ }^{70}$ Ibid., 19.

${ }^{71}$ McDonald, "Is There a Manx Context for the Lewis Chessmen?" 98.

${ }^{72}$ Ibid., 109.

${ }^{73}$ Ibid., 96. 